\title{
High-Throughput Sequencing Identifies Novel Viruses in Nectarine: Insights to the Etiology of Stem-Pitting Disease
}

\author{
D. E. V. Villamor, T. A. Mekuria, S. S. Pillai, and K. C. Eastwell
}

Department of Plant Pathology, Washington State University-Irrigated Agriculture Research and Extension Center, Prosser 99350. Accepted for publication 9 January 2016.

\begin{abstract}
Villamor, D. E. V., Mekuria, T. A., Pillai, S. S., and Eastwell, K. C. 2016. High-throughput sequencing identifies novel viruses in nectarine: Insights to the etiology of stem-pitting disease. Phytopathology 106:519-527.

Recent studies have shown the superiority of high-throughput sequencing (HTS) technology over many standard protocols for pathogen detection. HTS was initiated on fruit tree accessions from disparate sources to improve and advance virus-testing procedures. A virus with genomic features resembling most closely that of the recently described Nectarine stem-pitting-associated virus, putative member of genus Luteovirus, was found in three nectarine trees (Prunus persica cv. nectarina), each exhibiting stem-pitting symptoms on the woody cylinder above the graft union. In these samples, HTS also

revealed the presence of a coinfecting virus with genome characteristics typical of members of the genus Marafivirus. The same marafivirus- and luteovirus-like viruses were detected in nonsymptomatic nectarine and peach selections, indicating only a loose relationship between these two viruses with nectarine stem-pitting disease symptoms. Two selections infected with each of these viruses had previously tested free of known virus or virus-like agents using the current biological, serological, and molecular tests employed at the Clean Plant Center Northwest. Overall, this study presents the characterization by HTS of novel marafivirus- and luteovirus-like viruses of nectarine, and provides further insights into the etiology of nectarine stem-pitting disease. The discovery of these new viruses emphasizes the ability of HTS to reveal viruses that are not detected by existing protocols.
\end{abstract}

Nectarine (Prunus persica cv. nectarina) is an economically valuable stone fruit produced for the fresh market in the United States, primarily in California (USDA-NASS 2014). At least 12 virus species from genera belonging to the families Betaflexiviridae, Bromoviridae, Closterviridae, Comoviridae, Potyviridae, Secoviridae, and Tombusviridae are documented in fruit trees (Martelli et al. 2011). Plum pox virus (Barba et al. 2011), Peach mosaic virus (Larsen et al. 1998), and Tomato ringspot virus (ToRSV) (Powell et al. 1991) are among the viruses that induce symptoms in nectarine, whereas some viruses such as Cherry virus A (Jelkmann 1995) are not associated with acute symptom expression.

Many viruses of fruit trees have a protracted impact on the growth and physiology of affected trees; their economic significance may only become realized years after infection (Hadidi and Barba 2011). Because no therapeutic treatments are commercially available for these viruses, removal of infected trees and control of insect vectors, if known, are critical management strategies to limit or prevent spread of a virus in affected orchards. The use of virus-tested planting material produced either by a combination of heat therapy and microshoot tip grafting or from meristem culture (Laimer and Barba 2011) is an exclusionary measure to prevent the initial introduction of viruses into the production system. Over time, this strategy has been effective in reducing the incidence of most diseases caused by viruses and virus-like agents.

Clean plant programs ensure that fruit tree planting material in foundation orchards is free of economically important viruses. This is made possible by a combination of molecular, serological, and biological tests to detect agents and diseases that affect fruit trees. However, new and emerging viruses have been discovered in recent

Corresponding author: D. E. V. Villamor; E-mail address: dvillamor@wsu.edu

*The $\boldsymbol{e}$-Xtra logo stands for "electronic extra" and indicates that one supplementary figure and two supplementary tables are published online.

http://dx.doi.org/10.1094/PHYTO-07-15-0168-R

(C) 2016 The American Phytopathological Society years through the use of high-throughput sequencing technology (HTS) (also known as deep sequencing or next-generation sequencing) (Al Rwahnih et al. 2009; Donaire et al. 2009; Marais et al. 2015; Radford et al. 2012). For clean plant programs, adoption of this technology is highly advantageous, not only for enhancing the speed at which a wide range of known pathogens are detected but also for detecting novel or potential pathogens for which other diagnostic tools are not yet available.

To improve and advance virus-testing procedures, HTS was applied to a number of fruit tree selections from diverse sources. Two viruses, one that is a novel virus with genome characteristics typical of members of the genus Marafivirus and another one resembling Nectarine stem-pitting-associated virus ( $\mathrm{NSPaV})$, putative member of the genus Luteovirus, were detected in nectarine selections expressing stem-pitting symptoms. These viruses were not detected by current approved biological, serological, or molecular testing protocols (Jelkmann 2004). This study presents the characterization by HTS of novel viruses of nectarine, and provides some insights into the possible relationship between them and the presence of stempitting symptoms of nectarine.

\section{MATERIALS AND METHODS}

Virus source trees. The following sets of virus source trees were used: (i) budwood of nonsymptomatic nectarine trees, designated 12C51 and 12P42, that had been indexed free of known pathogens using standard testing procedures; and (ii) budwood of nectarine trees from California designated SF04522C, SF04522D, SF04522E, SF06176, SF05211, and SF07176 that exhibited stempitting symptoms on the woody cylinder of the scion of source trees. In each case, references trees (two trees per sample) were produced by chip budding onto $P$. persica 'Boone County' seedlings that had previously been confirmed by reverse-transcription polymerase chain reaction (RT-PCR) to be free of the luteovirus and marafiviruses described below. The reference trees were subsequently maintained in a United States Department of Agriculture Animal and Plant Health Inspection Service-compliant growth room under permit number 
P526P-14-03889. A single reference tree from each of three samples (12C51, SF04522E, and 12P42) was sacrificed after two growing seasons in order to inspect for abnormalities in the woody cylinder in the scion and rootstock portions of the propagated tree. Additionally, two peach trees (one 2-year old tree, designated 14F44, and one 10-year old tree, designated R6T29) were also examined for woody cylinder abnormalities.

Samples 12C51, 12P42, SF04522C, SF04522D, and SF04522E were subjected to the following virus testing procedure at the Clean Plant Center Northwest (CPCNW) located at Washington State University, Prosser: (i) enzyme-linked immunosorbent assay (ELISA) tests for Prune dwarf virus (antibody source: CPCNW, Washington State University, Prosser), Prunus necrotic ringspot virus (AC Diagnostics, Fayetteville, AR), Cherry leafroll virus (Bioreba, Longmont, $\mathrm{CO}$ ), and the generic potyvirus test (Agdia, Elkhart, IN); (ii) RT-PCR for members of the tricho-, fovea-, and capilloviruses (Foissac et al. 2005) Little cherry virus 1 (Bajet et al. 2008), Little cherry virus 2 (Eastwell and Bernardy 2001), Plum bark necrosis stem-pitting-associated virus (Al Rwahnih et al. 2007), Hop stunt viroid (Kusano and Shimomura 1997), and Peach latent mosaic viroid (K. C. Eastwell, unpublished), plus PCR assays for fruit tree phytoplasmas (Skrzeczkowski et al. 2001) and for the phytopathogenic bacteria Xylella (Minsavage et al. 1994); and (iii) biological woody indexing on P. avium 'Bing', 'Sam', and 'Canindex1', $P$. serrulata 'Kwanzan', $P$. persica 'GF305', Prunus hybrid 'Shiro plum', and P. tomentosa. Additional RT-PCR tests for the presence of ToRSV and Tobacco ringspot virus (TRSV) (K. C. Eastwell, unpublished) were performed on SF04522C, SF04522D, and SF04522E.

Samples received subsequently (namely, SF06176, SF05211, and SF07176) that showed stem-pitting symptoms on the woody cylinder were not subjected to the current pathogen-testing protocols at CPCNW but subjected to HTS only.

HTS and analysis. Total RNA was extracted from dormant buds and bark scrapings of each sample, as previously described (Villamor and Eastwell 2013). For sample 12C51, plant ribosomal RNA (rRNA) was removed from $5 \mu \mathrm{g}$ of total RNA using Ribo-Zero Magnetic Kit for Plant Root (Epicenter, Madison, WI). The resulting rRNA-depleted sample was submitted for library construction using the Illumina TruSeq RNA Preparation Kit followed by 101-bp pairedend read HTS on the Illumina HiSEquation 2000 platform with 12-sample bar-coded multiplexing (Center for Genome Research and Biocomputing, Oregon State University, Corvallis).

Total RNA from SF04522C, SF04522D, and SF04522E were pooled together, whereas RNA extracts from SF06176, SF05211, SF07176, and 12P42 were subjected to HTS individually. At least $1.5 \mu \mathrm{g}$ of RNA per sample was submitted for library construction using the Illumina TruSeq Stranded Total RNA Sample Preparation kit with Plant Ribo-Zero and 50-bp single-end read HTS on the Illumina HiSEquation 2000 platform with multiplexing (Microarray and Genomic Analysis Core Facility, Huntsman Cancer Institute, University of Utah, Salt Lake City). Analyses of the raw sequencing data were performed as previously described (Villamor et al. 2015) using CLC Genomics Workbench 5.1 (CLC Bio, Aarhus, Denmark), except that only $P$. persica sequences were subtracted from trimmed sequence reads. Data from each sequencing reaction were analyzed separately. The resulting reads from 50-bp single-end HTS (from pooled samples of SF04522C, SF04522D, and SF04522E and from individual samples of SF06176, SF05211, SF07176, and 12P42) were assembled into contigs with a minimum cut-off size of $75 \mathrm{bp}$, whereas reads from 101-bp paired-end HTS (sample 12C51) were assembled into contigs with a cut-off of $150 \mathrm{bp}$.

Sequences were edited and assembled using the BioEdit software (Hall 1999). Multiple sequence alignments were performed with MUSCLE (Edgar 2004) and phylogenetic trees were assembled with 1,000 bootstrap replicates using the maximum-likelihood method in Mega6 (Tamura et al. 2013). Sequences of representative members of the genera Marafivirus, Tymovirus, Maculavirus, Luteovirus, Polerovirus, and Enamovirus were obtained from the
National Center for Biotechnology Information (NCBI) GenBank database and included in the analysis.

Validation of the presence of viruses revealed by HTS. The presence of a marafivirus-like sequence was confirmed by onetube RT-PCR using primer pairs 12C51 2719F/3131R and 12C51 4479F/4863R (Supplementary Table S1), designed to amplify a region within two contigs recovered from HTS of sample 12C51. The resulting amplicons were sequenced directly. To verify the presence of the luteovirus-like sequence, a one-tube RT-PCR was performed on total RNA extracted from leaves and shoots from each sample using primer pair Lut 1254F/2250R, designed from the sequence of a $4.9-\mathrm{kb}$ contig recovered from pooled samples of SF04522C, SF04522D, and SF04522E. Amplicons produced by Lut 1254F/2250R were cloned into pCR 2.1 TOPO (Life Technologies, Carlsbad, CA) and three different clones from each tree were selected for sequencing by primer walking.

Further verification of the presence of the virus-like sequences, as well as filling sequence gaps between contigs, was performed using long-range RT-PCR. A one-tube RT-PCR format was employed following a previously described protocol (Villamor and Eastwell 2013), except that a high-fidelity Taq polymerase was used (SuperScript III One-Step RT-PCR System with Platinum Taq Hifi; Life Technologies). A two-tube format was performed by employing first-strand cDNA synthesis with primer FRSTRD, as described previously (Eastwell et al. 2009), and PCR using PrimeSTAR HS DNA polymerase (Takara Bio Inc., Mountain View, CA). For the marafivirus-like sequence, primer pairs CSOB 2F/CSDaV 6772R and CSOB 1238F/CSDaV 5065R were used to obtain 6.7- and 3.8-kb amplicons, respectively, in a two-tube format. Primer pair Mar-1F/Mar-1R was used to yield a 4.4-kb amplicon in a one-tube format. For the luteovirus-like sequence, a $4.4-\mathrm{kb}$ product was amplified using primer pair Lut 404F/4838R in a one-tube format.

The 5' terminus of each virus was determined by rapid amplification of cDNA ends (RACE; Life Technologies) using virus-specific primers. To determine the $3^{\prime}$ terminus, total RNA of infected plants were polyadenylated using a Poly(A)-tailing kit (Life Technologies) followed by cDNA synthesis with SuperScript III reverse transcription (Life Technologies) primed with primer FRSTRD2. Subsequent PCR was performed using appropriate virus-specific primers. In total, 10 different clones corresponding to each virus from each source tree were sequenced.

Graft transmission. To verify that the sequences were associated with graft-transmissible agents, transmissibility was demonstrated by grafting buds from $12 \mathrm{C} 51$ onto four $P$. persica Boone County peach seedlings (two buds per seedling). Bark patches from SF04522E were grafted onto eight $P$. tomentosa and four $P$. persica Boone County seedlings and three $P$. avium Bing seedlings on 'Mazzard' seedling rootstock (three patches per tree). Graft-inoculated trees were allowed to grow and were monitored for symptom expression for 90 days after inoculation. Transmission of viruses was verified by RT-PCR with primer pairs 12C51 2719F/3131R and 12C51 4479F/4863R to detect the marafivirus-like sequence and primer pairs Lut 1254F/2250R and NSPaVF/NSPaVR (Bag et al. 2015) to detect the luteovirus-like sequence. In each case, both scion and seedling rootstock portions of the graft-inoculated trees were tested. Total RNA was extracted as described previously (Villamor and Eastwell 2013), except that green shoots, petioles, and leaves were used instead of dormant buds. The quality of RNA in all RT-PCR tests was established by performing a separate RT-PCR for NADH dehydrogenase subunit 5 using primers NAD5-s/NAD5-as (Menzel et al. 2002). In addition to the trees used in graft transmission studies, two trees (14F44 and R6T29) were examined for woody cylinder abnormalities and were tested for the presence of the luteovirus-like and marafivirus-like sequences by RT-PCR.

\section{RESULTS}

Analysis of HTS data. The total number of trimmed sequence reads ranged from 15 to 34 million, which resulted in the assembly 
of 1,484 to 7,151 contigs after host sequence reduction (Supplementary Table S2). These contigs were annotated by BLASTN and BLASTX analyses against the nucleotide $\mathrm{nr} / \mathrm{nt}$ database of NCBI. Known fruit tree viruses that are previously described and characterized viruses where full or partial genome sequences are available in public databases were not identified in any of the samples. However, separate contigs from SF04522C-E and 12P42 contained sequences with highest identity values to members of the genus Luteovirus, family Luteoviridae, and to genus Marafivirus, family Tymoviridae (Table 1). Analysis of HTS sequence data from 12C51, SF05211, and SF06176 identified sequences related to members of the genus Marafivirus (Table 1). Contigs that showed identities to marafi-, tymo-, and maculaviruses correspond to segments from a novel marafivirus. Full-genome assembly of the marafivirus-like virus was pursued for samples 12C51, SF04522E, and 12P42. The luteovirus-like sequences from SF04522C-E and $12 \mathrm{P} 42$ showed high nucleotide identity values to the previously reported NSPaV but represent different strains of the virus. Full genomic sequences of the different strains of the luteovirus were determined for samples SF04522E and 12P42.

Graft transmission. Visual observation of trees that were graft inoculated with buds from 12C51 or bark patches from SF04522E did not reveal any visible symptoms suggestive of virus infection. However, RT-PCR results revealed the presence of the marafiviruslike virus in both the scion and rootstock portions of the 12C51 graftinoculated $P$. persica Boone County. Moreover, all woody indicators (P. tomentosa, P. avium Bing, and P. persica Boone County) graft inoculated with bark patches from SF04522E tested positive by RT-PCR for both marafivirus-like and luteovirus-like viruses. The identity of the RT-PCR amplicons was further confirmed by direct sequencing. All recipient trees were tested prior to inoculation to verify the absence of detectable levels of the virus sequences revealed by HTS. Taken together, these results demonstrate that both viruses are graft transmissible to multiple Prunus spp.

Genome assembly and organization. Luteovirus-like virus. BLASTX analysis of sequences obtained for the pooled total RNA from samples SF04522C, SF04522D, and SF04522E revealed a long contig consisting of 4,942 nucleotides (nt) that showed $>99 \%$ identity value to the reported $\mathrm{NSPaV}$, a putative member of the genus Luteovirus. Because this contig was recovered from pooled samples, reference trees from each individual sample were tested by RT-PCR using primer pair Lut $1254 \mathrm{~F} / 2250 \mathrm{R}$. The amplicon sequences from the three samples showed 98 to $99 \%$ identity to each other, suggesting that all three samples were infected with the same species of the virus. Subsequent determination of full-length sequences by RT-PCR and by 5'- and $3^{\prime}$-RACE was generated only for SF04522E (Fig. 1A).

BLASTX analysis identified 13 contigs recovered from $12 \mathrm{P} 42$ with highest identity values (95 to 99\%) to NSPaV (Bag et al. 2015). These contigs were mapped to the full genome sequence of the virus sequence from SF04522E. RT-PCR was used to complete sequence information corresponding to gaps between contigs, and the $5^{\prime}$ - and $3^{\prime}$-terminal sequences were determined by $5^{\prime}$ - and $3^{\prime}$-RACE, respectively (Supplementary Fig. 1a).

The complete genomes of the NSPaV-like viruses from SF04522E and 12P4242 consist of 4,991 nt (GenBank accessions KT273409 and KT273410) with 5' and $3^{\prime}$ untranslated regions (UTR) of 131 and $671 \mathrm{nt}$, respectively, similar to NSPaV (Bag et al. 2015). A conserved motif (GUAAAG) found in most luteoviruses (Domier et al. 2002) was present at multiple sites in the genome: nucleotide positions 2 to $7,1,326$ to $1,331,2,627$ to 2,632, and 3,167 to 3,132 for both SF04522E and $12 \mathrm{P} 42$. Four open reading frames (ORF) were predicted that showed organization similar to that of members of the genus Luteovirus (Fig. 1A). ORF1 (nucleotide position 132 to 1,118 ) and ORF2 (nucleotide position 1,115 to 2,674 ) constitute the putative $\mathrm{P} 1$ and $\mathrm{P} 2$ proteins of the viral replicase, the latter containing the RNA-dependent RNA polymerase (RdRp) active site (Domier 2012). Two conserved elements required for the expression of ORF2 via a-1 ribosomal frameshift were also found in the genome of the luteovirus-like virus from SF04522E and 12P42: (i) the heptanucelotide canonical slippery sequences 'GGDUUUU' (GGUUUUU for both SF04522E and 12P42) found at the junction of ORF1 and ORF2; and (ii) an element that could form a loop structure located $30 \mathrm{nt}$ downstream from the slippery sequence with the sequence 'CCCKUUUUUCUCUUUUGGG' ( $\mathrm{K}=\mathrm{U}$ and $\mathrm{G}$ for SF04522E and 12P42, respectively). ORF3 (nucleotide position 2,740 to 3,360) encodes the putative coat protein $(\mathrm{CP})$ and is immediately followed by ORF5, which is a CP read-through protein that is known to be important for aphid transmission (Brault et al. 1995; Chay et al. 1996) and is generated by in-frame read-through of the ORF3 stop codon (Miller et al. 1995). Similar to NSPaV, ORF4, a putative movement protein, is also absent in the luteovirus-like virus sequences from samples SF04522E and 12P42.

Marafivirus-like virus. BLASTX analysis of sequences from sample 12C51 identified five contigs that showed distant homology to two marafiviruses; namely, Citrus sudden death-associated virus $(\mathrm{CSDaV})$ and Oat blue dwarf virus (OBDV) (Table 1). The relative position and orientation of the five contigs were predicted by mapping them to the genome of CSDaV and the authenticity of each contig sequence and sequence gaps between contigs were verified by RT-PCR (Supplementary Fig. 1b).

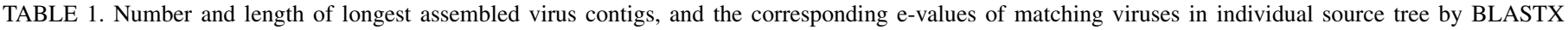
analysis

\begin{tabular}{|c|c|c|c|c|c|c|}
\hline Source tree & Virus family (genus) & BLASTX virus $^{\mathrm{a}}$ & $N^{\mathrm{b}}$ & Longest contigc & BLASTX e-value range & Identity $(\%)$ \\
\hline $12 \mathrm{C} 51$ & Tymoviridae (Marafivirus) & CSDaV (3), OBDV (2) & 5 & 1,473 & 9.59 e- $40-3.36$ e- 8 & $33.6-70.9$ \\
\hline \multirow[t]{2}{*}{ SF04522C-E } & Luteoviridae (Luteovirus) & NSPaV (1) & 1 & 4,942 & 0 & 99.0 \\
\hline & Tymoviridae (Marafivirus) & $\begin{array}{l}\text { CSDaV (4), OBDV (4), BVS (1), GAMaV } \\
\text { (1), GRVFV (1), MRFV (1), SwMV(1) }\end{array}$ & 13 & 238 & 9.14 e-43-6.23 e-9 & $76.5-87.2$ \\
\hline \multirow[t]{4}{*}{$12 \mathrm{P} 42$} & Luteoviridae (Luteovirus) & NSPaV (13) & 13 & 644 & 6.52 e- $150-3.44$ e- 14 & $94.8-100$ \\
\hline & Tymoviridae (Marafivirus) & $\begin{array}{l}\text { CSDaV (13), OBDV (7), BVS (2), GAMaV } \\
\text { (1), GSyV-1 (1), MRFV (1), SwMV (1) }\end{array}$ & 26 & 392 & 3.06 e- $65-8.84$ e- 4 & $67.9-80.6$ \\
\hline & Tymoviridae (Tymovirus) & APLV (1) & 1 & 88 & 5.46 e -12 & 100 \\
\hline & Tymoviridae (Maculavirus) & GRGV (1) & 1 & 123 & $2.6 \mathrm{e}-17$ & 92.5 \\
\hline SF05211 & Tymoviridae (Marafivirus) & CSDaV (4), OBDV (2), BVS (1), MRFV (1) & 8 & 116 & $3.33-17-9.56$ e-5 & $69.7-94.7$ \\
\hline SF06176 & Tymoviridae (Marafivirus) & CSDaV (2), MRFV (1), OBDV (1) & 4 & 147 & 7.32 e- $-21-3.66$ e-9 & $61.5-81.2$ \\
\hline SF07176 & $\mathrm{n} / \mathrm{a}^{\mathrm{d}}$ & None & $\mathrm{n} / \mathrm{a}$ & $\mathrm{n} / \mathrm{a}$ & $\mathrm{n} / \mathrm{a}$ & $\mathrm{n} / \mathrm{a}$ \\
\hline
\end{tabular}

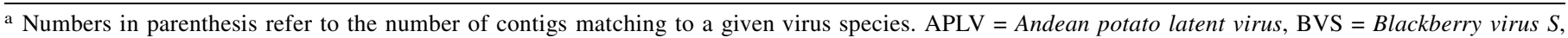
$\mathrm{CSDaV}=$ Citrus sudden death-associated virus, GAMaV = Grapevine asteroid mosaic-associated virus, GRVFV $=$ Grapevine rupestris vein feathering virus, GSyV-1 = Grapevine Syrah virus 1, MRFV = Maize rayado fino virus, NSPaV = Nectarine stem-pitting-associated virus, OBDV = Oat blue dwarf virus, and SwMV = Switchgrass mosaic virus.

b Number of virus contigs.

c Contig length measured in number of nucleotides.

d Abbreviation: $\mathrm{n} / \mathrm{a}=$ not applicable. 
BLASTX analysis identified 13 marafivirus-like contigs for SF04522C-E, and 26, 1, and 1 marafi-, tymo-, and maculavirus-like virus contigs, respectively, for $12 \mathrm{P} 42$. Corresponding contigs were initially mapped to the full genome sequence of the marafiviruslike virus from $12 \mathrm{C} 51$ in order to assemble the full virus genomic sequence from each sample. Amplicon sequences derived from samples SF04522C, SF04522D, and SF04522E with primer pairs 12C51 2719F/3131R and 12C51 4479F/4863R showed 99 to $100 \%$ identity to each other, thus showing that the three samples harbored identical species of a marafivirus-like virus.

The complete genomes of the novel marafivirus-like viruses from 12C51, SF04522E, and 12P42 were determined and consist of $6,421,6,471$, and $6,701 \mathrm{nt}$, respectively, excluding the poly(A) tail (GenBank accessions KT273411, KT273412, and KT273413). A single uninterrupted ORF, yielding a putative product of 2,055 amino acids (aa) for 12C51 and SF04522E and 2,137 aa for 12P42, was identified in the sense orientation (Fig. 1B). The discrepancy in the sizes of putative product is due to an insertion of 82 aa located at the amino-terminal portion of the polyprotein present in $12 \mathrm{P} 42$ but absent in 12C51 and SF04522E. This ORF is flanked by UTR of 74 and $179 \mathrm{nt}$ for $12 \mathrm{C} 51,129$ and $174 \mathrm{nt}$ for SF04522E, and 108 and $179 \mathrm{nt}$ for $12 \mathrm{P} 42$ at the $3^{\prime}$ and $5^{\prime}$ ends, respectively. The predicted amino acid sequence of the protein contains the conserved motifs associated with marafiviruses (Dreher et al. 2005); namely, viral methyltransferase (pfam 01660), tymovirus endopeptidase (pfam 05381), viral RNA helicase (pfam01443), RdRp (pfam00978), and tymovirus CP (pfam00983) (Fig. 1B).

The putative movement gene that overlaps the polyprotein of Maize rayado fino virus (MRFV) (Hammond and Ramirez 2001) is lacking in the marafivirus-like virus sequence of all three isolates (12C51, SF04522E, and 12P42). Similarly, a putative movement protein gene has not been identified in the marafiviruses CSDaV (Maccheroni et al. 2005), Switchgrass mosaic virus (SwMV) (Agindotan et al. 2012), or OBDV (Edwards et al. 1997).

Sequence comparison and phylogenetic analysis. In pairwise comparisons, the full genomic nucleotide sequences of the luteovirus from SF04522E and 12P42 were 95\% identical to each other, with sequences from SF04522E and 12P42 showing > 99 and $95 \%$ nucleotide identities, respectively, to the genome of NSPaV. Furthermore, the full genome, RdRp, and $\mathrm{CP}$ region sequences revealed highest identities with members of the genus Luteovirus (Table 2). Currently, a virus is considered a new species within the family Luteoviridae if the amino acid sequence of any gene product differs by $>10 \%$ from other species in the family (Domier 2012).

TABLE 2. Percent nucleotide and amino acid identities between Nectarine stem-pitting-associated virus (NSPaV) Nectarine virus $\mathrm{M}(\mathrm{NeVM})$ and members of the family Luteoviridae, and between Nectarine virus $\mathrm{M}(\mathrm{NeVM})$ and members of the family Tymoviridae ${ }^{\mathrm{a}}$

\begin{tabular}{llll}
\hline Virus sequence comparison $^{\text {b }}$ & $\begin{array}{c}\text { Whole } \\
\text { genome }\end{array}$ & Replicase & CP \\
\hline NSPaV comparison & & & \\
NSPaV (Bag et al. 2015) & $95-99$ & $96-99$ & 99 \\
NSPaV isolates (SF04522E, 12P42) & 95 & 96 & 99 \\
NSPaV and luteoviruses & $38-43$ & $61-66$ & $26-39$ \\
NSPaV and poleroviruses & $27-29$ & $6-11$ & $30-38$ \\
NSPaV and enamovirus & 28 & $8-9$ & 24 \\
NeVM comparison & & & \\
NeVM isolates (12C51, SF04522E, & & & \\
12P42) & $85-97$ & $91-99$ & $97-100$ \\
NeVM and marafiviruses & $51-60$ & $48-63$ & $37-72$ \\
NeVM and tymoviruses & $45-46$ & $38-39$ & 27 \\
NeVM and maculavirus & $44-49$ & $37-43$ & $21-27$ \\
\hline
\end{tabular}

a Values indicate percent nucleotide identities for whole-genome comparison whereas amino acid identities used replicase and coat protein (CP) comparisons. For NSPaV, the identity values were derived from the RNAdependent RNA polymerase region of the $\mathrm{P} 2$ protein (open reading frame 2) whereas the whole replicase coding regions were used for NeVM.

b In all, 9 luteoviruses, 7 poleroviruses, and 1 enamovirus were used in sequence comparisons with NSPaV from SF04522E and 12P42; and 6 marafiviruses, 10 tymoviruses, and 1 maculavirus were used in sequence comparisons with NeVM from 12C51, SF04522E, and 12P42. Identification of virus sequences used in this comparison is provided in Figure 2.
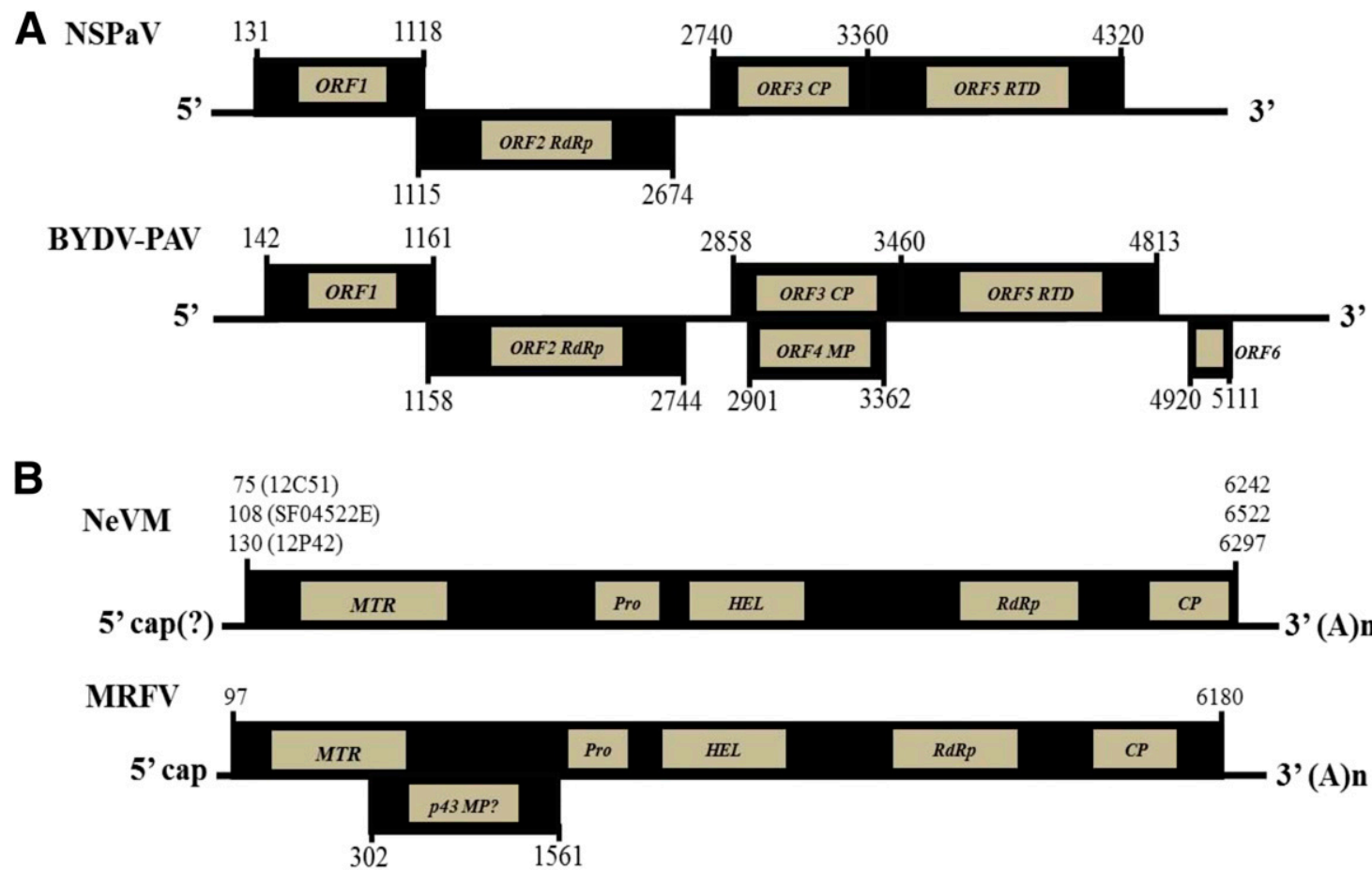

Fig. 1. Genome organization and structure of $\mathbf{A}$, Nectarine stem-pitting-associated virus (NSPaV) and $\mathbf{B}$, Nectarine virus $\mathrm{M}$ (NeVM) relative to the type species of the respective genera where they belong: genus Luteovirus, Barley yellow dwarf virus PAV (BYDV-PAV), and genus Marafivirus, Maize rayado fino virus $(\mathrm{MRFV}) . \mathrm{ORF}=$ open reading frame, $\mathrm{MTR}=$ methyl transferase, Pro $=$ protease, $\mathrm{Hel}=$ helicase, $\mathrm{RdRp}=\mathrm{RNA}$-dependent $\mathrm{RNA}$ polymerase, $\mathrm{CP}=\mathrm{coat}$ protein, $\mathrm{RTD}=$ read-through protein, and $\mathrm{MP}=$ movement protein . 


\section{A NSPaV coat protein phylogeny}

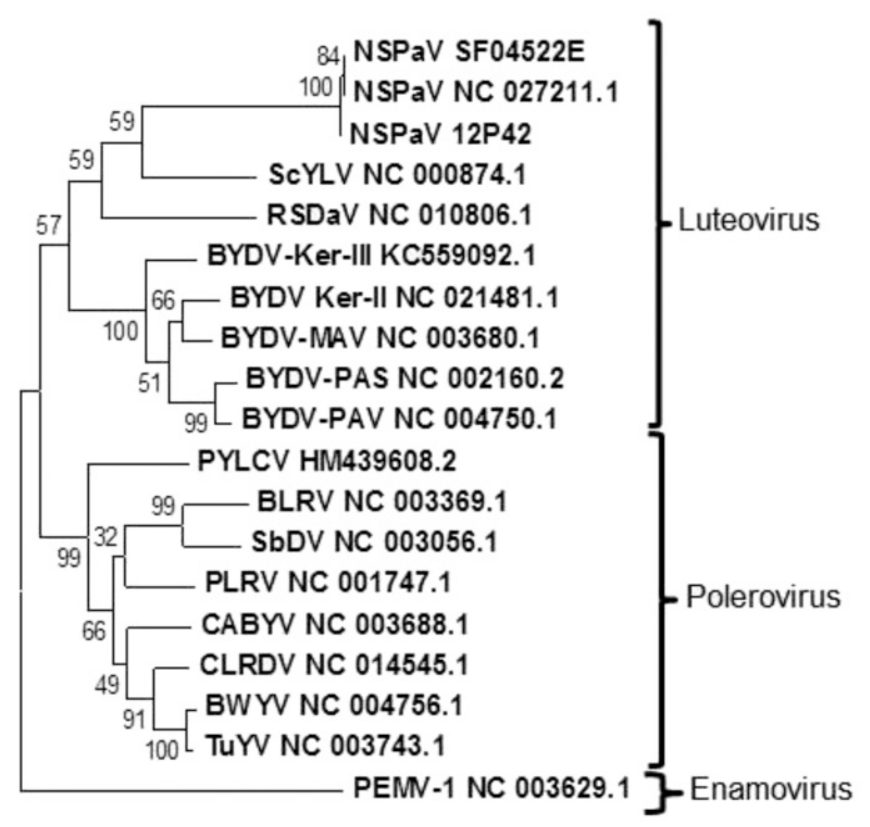

$\stackrel{\longmapsto}{0.2}$

\section{NeVM coat protein phylogeny}

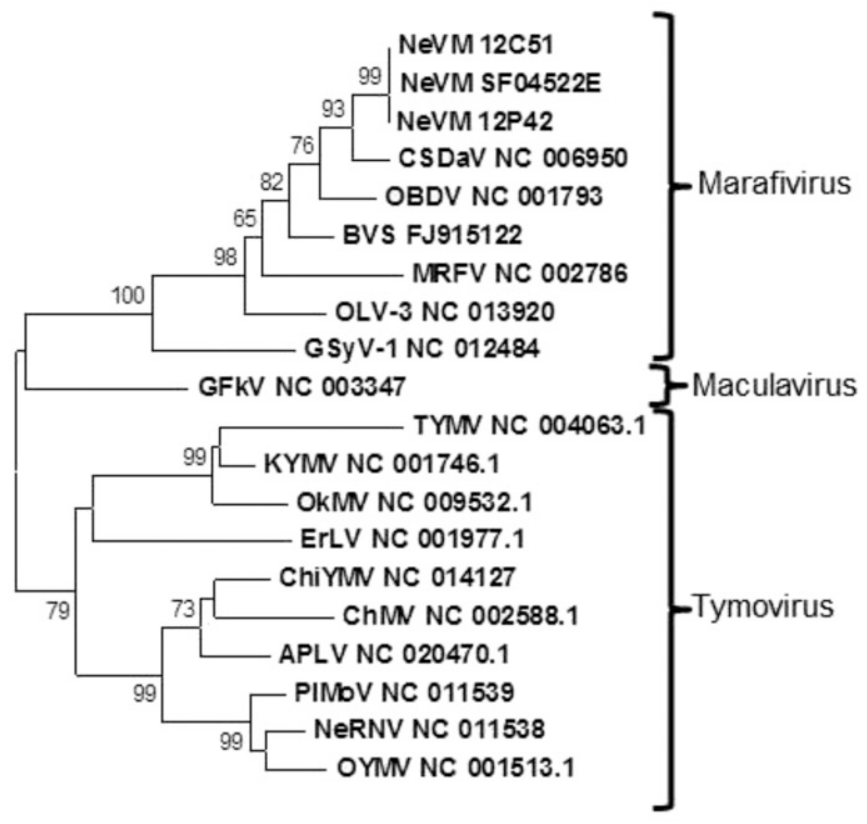

$\stackrel{5}{0.2}$

\section{B NSPaV full genome phylogeny}

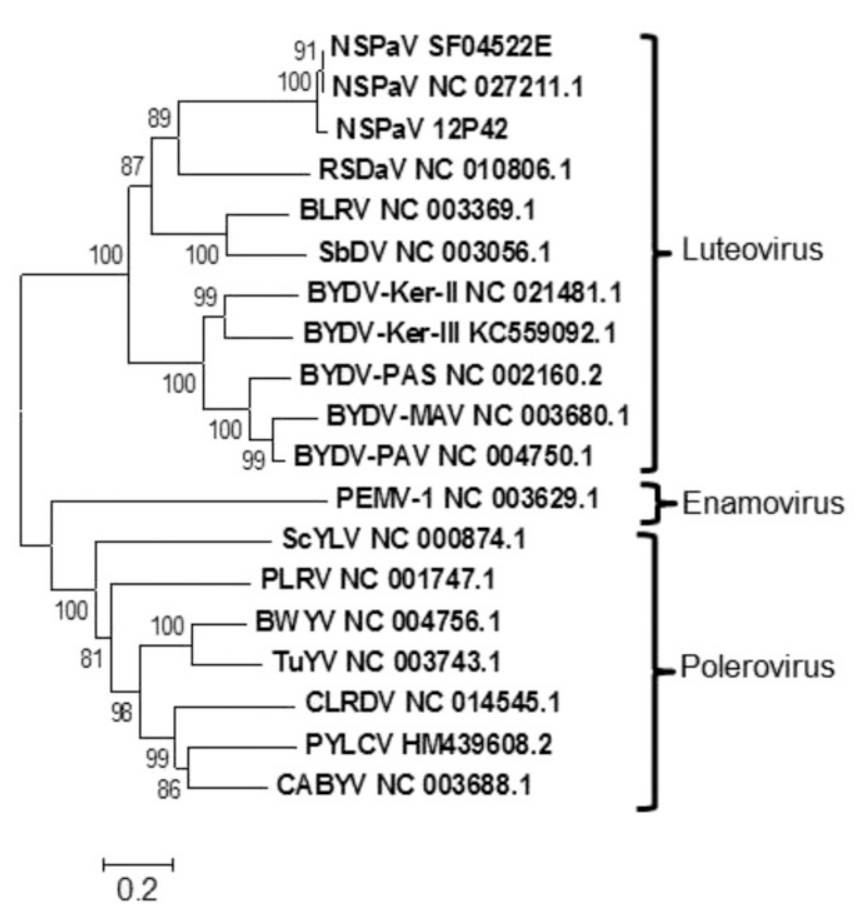

D NeVM full genome phylogeny

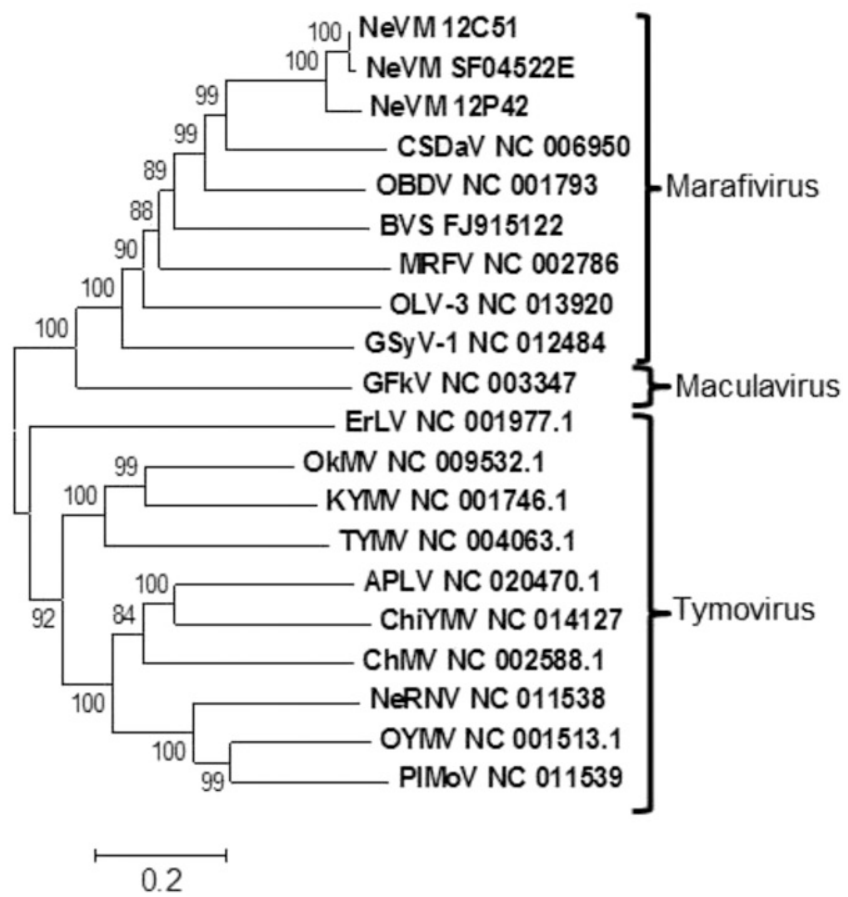

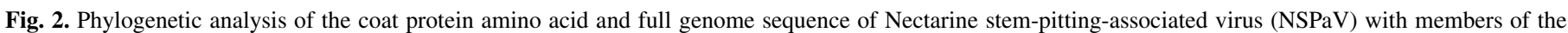

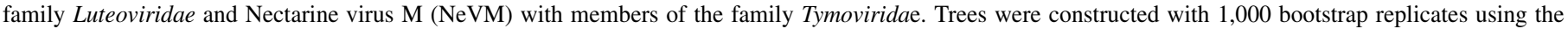

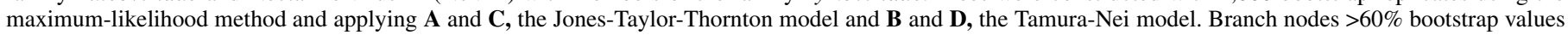

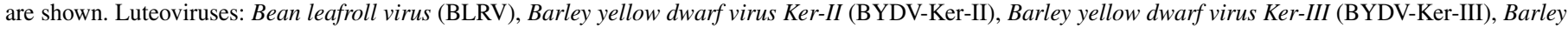

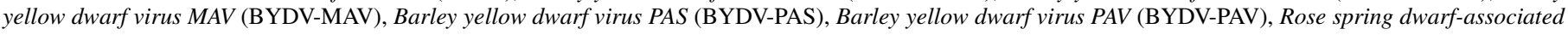

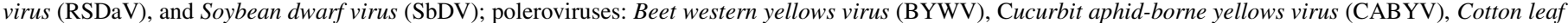

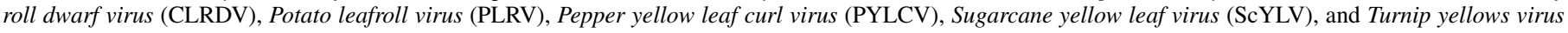

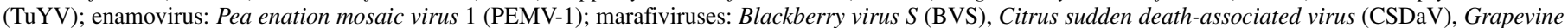

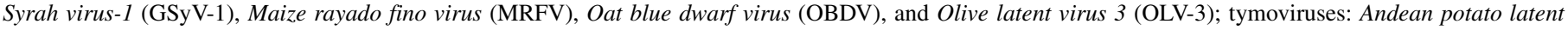

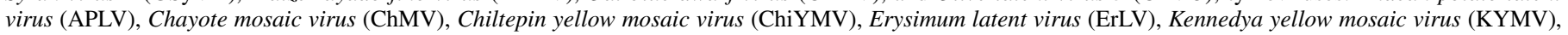

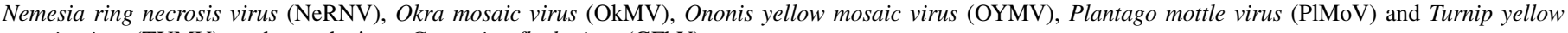
mosaic virus (TYMV); and maculavirus: Grapevine fleck virus (GFkV). 
Using this guideline, the luteoviruses from SF04522E and $12 \mathrm{P} 42$ and NSPaV would be considered a single species within family Luteoviridae. The virus can be placed in the genus Luteovirus based on its genome organization similarity to other members of this genus. Phylogenetic analyses of the complete nucleotide and $\mathrm{CP}$ amino acid sequences showed clustering of the luteoviruses from SF04522E and 12P42 with viruses belonging to the genus Luteovirus but most closely to NSPaV (Bag et al. 2015) (Fig. 2A and $\mathrm{B})$. Based on genome organization and sequence identity values, it is evident that the luteoviruses from SF04522E and 12P42 and from $\mathrm{NSPaV}$ are identical viruses.

The complete nucleotide sequence of the marafivirus-like viruses from 12C51, SF04522E, and 12P42 shared 85 to $97 \%$ nucleotide identities to each other. Within the family Tymoviridae, the marafivirus-like sequence showed greatest nucleotide identities to members of genus Marafivirus, ranging from 45 to $62 \%$, and only 45 to 46 and 41 to $42 \%$ nucleotide identities to members of the genus Tymovirus and to Grapevine fleck virus of the genus Maculavirus, respectively (Table 2). Pairwise comparisons of the amino acid sequences of the $\mathrm{CP}$ and replicase coding regions yielded the same trend, with greater identities observed between members of the Marafivirus genus than with the genera Maculavirus and Tymovirus (Table 2). The identity values at the whole genome and $\mathrm{CP}$ are in agreement with the species demarcation criteria of the International Committee on Taxonomy of Viruses for the genus Marafivirus, which is $<70 \%$ nucleotide for whole genome and $<85 \%$ amino acid for CP (King et al. 2012; Martelli et al. 2002), suggesting that this is a distinct species within the genus Marafivirus. The novel marafivirus from 12C51, SF04522E, and 12P42 grouped with members of the genus Marafivirus but most closely with CSDaV (Maccheroni et al. 2005) (Fig. 2C and D). The suggested name for this virus is Nectarine virus $\mathrm{M}(\mathrm{NeVM})$.

Pathogen status of source and reference trees. Samples 12C51, SF04522C, SF04522D, SF04522E, and12P42 were tested free of any known fruit tree pathogens based on the current pathogen-testing protocols at CPCNW; induction of visible disease symptoms was not observed in any biological woody indicator, and all ELISA, PCR, and RT-PCR tests were negative. Samples SF04522C, SF04522D, and SF04522E were additionally tested by RT-PCR assays for TRSV and ToRSV, two nepoviruses that are associated with leaf and stem-pitting symptoms in Prunus spp.; these tests yielded negative results.

Neither HTS nor RT-PCR detected NSPaV in the original dormant budwood of trees SF06176, SF05211, and SF07176, whereas $\mathrm{NSPaV}$ was detected in budwood from samples SF04522C,
SF04522D, SF04522E, and 12P42. In all cases, actively growing reference trees propagated with this budwood tested positive by both procedures (Table 3 ). This suggests that virus concentration in extracts from dormant budwood were below the limits of detection by these methods in some samples. This may be a consequence of different physiological status of the budwood, the influence of cultivar on virus accumulation, or erratic distribution of virus in budwood. Similarly, NeVM was not detected by RTPCR or by HTS in extracts from budwood of sample SF0716 but was detected in all reference trees budded with that sample material.

Two-year-old reference trees made from 12C51, 12P42, and SF04522E were sacrificed in order to observe any visible abnormalities in the vascular system such as stem pitting. Examination of a reference tree made from SF04522E revealed stem pitting in the woody cylinder of the scion but not in the rootstock portion of the tree. In contrast, no stem pitting was observed in the woody cylinder of the scion or rootstock of $12 \mathrm{C} 51$ or $12 \mathrm{P} 42$ reference trees. RT-PCR tests of the reference trees revealed NSPaV and NeVM in samples SF04522E and $12 \mathrm{P} 42$, whereas only $\mathrm{NeVM}$ was detected in $12 \mathrm{C} 51$. In addition, examination of the woody cylinder did not reveal any abnormalities in the scion or rootstock of 14F44 or the scion of R6T29 (the rootstock of R6T29 was not examined). Both trees tested positive for NSPaV but not NeVM in RT-PCR. Direct sequencing of NSPaV amplicons (997 nt) from 14F44 and R6T29 revealed $>95 \%$ nucleotide identities to each other and $>94 \%$ identities to the corresponding sequence of the genomes of NSPaV from SF04522E and 12P42, and to NSPaV (Bag et. al 2015).

\section{DISCUSSION}

Increased application of HTS technology has resulted in the discovery of a large number of new plant viruses recently (Adams et al. 2009; Al Rwahnih et al. 2009; Coetzee et al. 2010; Elbeaino et al. 2014; Giampetruzzi et al. 2012; He et al. 2015; Marais et al. 2015; Poojari et al. 2013; Vives et al. 2013). Typically, this technology is used to identify candidate pathogens that may be associated with disease symptoms in plants (Adams et al. 2009). HTS has also been applied to virus-tested plant materials to conduct a census of viruses that were difficult to detect with older technologies (Al Rwahnih et al. 2011; Kreuze et al. 2009). In the present study, two viruses were discovered in nectarine by HTS. In one instance, the discovery of a marafivirus was serendipitous, resulting from a preliminary attempt to determine the reliability of conventional fruit tree virus-testing procedures. This virus was

TABLE 3. Detection of Nectarine stem-pitting-associated virus (NSPaV) and Nectarine virus $\mathrm{M}(\mathrm{NeVM})$ and symptomatology in the original budwood and references trees ${ }^{\mathrm{a}}$

\begin{tabular}{|c|c|c|c|c|c|c|c|c|}
\hline \multirow[b]{3}{*}{ Sample } & \multirow{2}{*}{\multicolumn{2}{|c|}{$\frac{\text { HTS }}{\text { Original budwood }}$}} & \multicolumn{4}{|c|}{ RT-PCR (positive/tested) ${ }^{\mathrm{b}}$} & & \\
\hline & & & \multicolumn{2}{|c|}{ Original budwood } & \multicolumn{2}{|c|}{ Reference tree } & \multicolumn{2}{|c|}{ Stem-pitting symptom } \\
\hline & NSPaV & $\mathrm{NeVM}$ & NSPaV & $\mathrm{NeVM}$ & $\mathrm{NSPaV}$ & $\mathrm{NeVM}$ & Original budwood & Reference tree \\
\hline SF04522C & + & + & $\mathrm{nt}$ & $\mathrm{nt}$ & $2 / 2$ & $2 / 2$ & + & $\mathrm{n} / \mathrm{e}$ \\
\hline SF04522D & + & + & $\mathrm{nt}$ & $\mathrm{nt}$ & $2 / 2$ & $2 / 2$ & + & $\mathrm{n} / \mathrm{e}$ \\
\hline SF04522E & + & + & nt & $\mathrm{nt}$ & $2 / 2$ & $2 / 2$ & + & + \\
\hline SF05211 & - & + & - & + & $2 / 2$ & $2 / 2$ & + & $\mathrm{n} / \mathrm{e}$ \\
\hline $12 \mathrm{P} 42$ & + & + & $\mathrm{nt}$ & $\mathrm{nt}$ & $2 / 2$ & $2 / 2$ & $\mathrm{n} / \mathrm{a}$ & - \\
\hline $14 \mathrm{~F} 44$ & $\mathrm{n} / \mathrm{a}$ & $\mathrm{n} / \mathrm{a}$ & $\mathrm{n} / \mathrm{a}$ & $\mathrm{n} / \mathrm{a}$ & $1 / 1^{\mathrm{c}}$ & $0 / 1$ & $\mathrm{n} / \mathrm{a}$ & - \\
\hline R6T29 & $\mathrm{n} / \mathrm{a}$ & $\mathrm{n} / \mathrm{a}$ & $\mathrm{n} / \mathrm{a}$ & $\mathrm{n} / \mathrm{a}$ & $1 / 1^{\mathrm{c}}$ & $0 / 1$ & $\mathrm{n} / \mathrm{a}$ & - \\
\hline
\end{tabular}

a HTS $=$ high-throughput sequencing, $n t=$ not tested, $\mathrm{n} / \mathrm{a}=$ not applicable, and $\mathrm{n} / \mathrm{e}=$ not examined, meaning that either the original budwood or reference tree for the particular sample was not examined for stem-pitting symptom. Plus (+) and minus (-) refer to presence and absence of stem-pitting symptoms, respectively.

b Number of positive trees/number of trees tested. Primer pairs Lut 1254F/2250R and NSPaVF/R were used for NSPaV whereas primer pairs 12C51 2719F/3131R and $12 \mathrm{C} 514479 \mathrm{~F} / 4863 \mathrm{R}$ were used for NeVM. All of the original budwood and reference trees that were indexed for NSPaV and NeVM also tested positive for the internal control NADH dehydrogenase subunit 5 using primers NAD5-s/NAD5-as.

${ }^{c}$ Direct sequencing of NSPaV amplicons from 14F44 and R6T29, generated using Lut 1254F/2250R primers, revealed >95\% nucleotide identities to each other and $>94 \%$ identities to the corresponding sequence of the genomes of NSPaV from SF04522E and 12P42, and to NSPaV (Bag et. al 2015). 
identified from an asymptomatic nectarine sample (12C51) that had been previously indexed free of known fruit tree pathogens by current rigorous testing procedures involving biological indexing on Prunus indicators along with a battery of serological and molecular tests (Jelkmann 2004). The second virus, a luteovirus from symptomatic nectarine samples (SF04522C, SF04522D, and SF04522E) showing stem-pitting symptoms of the wood cylinder, was also discovered by HTS. Current testing protocols failed to identify any known plant-pathogenic agent in the symptomatic samples. The symptomatic nectarine samples harbored the same Marafivirus species present in sample 12C51.

Concurrent with preparation of this article, a novel luteovirus sequence was reported (Bag et al. 2015). The sequence was detected through the use of HTS in nectarine samples showing stem-pitting symptoms in the woody cylinder; the suggested name of the virus sequence is NSPaV. The length of the genome is the same as the luteovirus detected in this study, sharing nucleotide identity values of $>99$ and $95 \%$ with isolates from SF04522E and 12P42, respectively. Based on whole-genome identity values, it is evident that NSPaV and the luteovirus from SF04522E are the same strains of the virus, whereas the luteovirus from $12 \mathrm{P} 42$ represented different strains. The novel marafivirus identified in this study represents a second virus associated with the nectarine exhibiting stem-pitting symptoms.

The results of this study indicate that stem-pitting symptoms in nectarine could be the result of the interaction between $\mathrm{NSPaV}$ and NeVM. This is based on the fact that all stem-pitted trees in this study harbored both viruses. However, the association is tenuous because these two viruses were also recovered from nonsymptomatic (without stem pitting) nectarine and peach samples with genetic backgrounds that differ from the samples that exhibited stem-pitting symptoms. It is also possible that the stem-pitting symptoms are a direct phenotypic expression of certain nectarine genotypes with a common parentage (such as SF04522, SF05211, SF06176, and SF07176). This possibility can be addressed only when trees of these genotypes are freed from these viruses; this is currently being pursued. Finally, the possibility of the involvement of specific variants of either $\mathrm{NSPaV}$ or $\mathrm{NeVM}$ or both in stem-pitting symptom expression cannot be overlooked. In this regard, it is interesting to note that viruses recovered from symptomatic and nonsymptomatic nectarine showed greater variability in NeVM than NSPaV $(85 \%$ full genome nucleotide identity of NeVM from SF04522E and 12P42, compared with $96 \%$ nucleotide identity of $\mathrm{NSPaV}$ ). Whether NeVM plays a greater role than NSPaV in stem-pitting symptom expression in nectarine is currently unknown but this aspect will be considered in future etiological studies of the disease. Although the symptoms ascribed to NSPaV and NeVM were only observed in nectarine, graft transmission showed that sweet cherry (P. avium) and Nanking cherry (P. tomentosa) are hosts for these viruses. This finding raises the importance of determining other possible routes of dissemination of these viruses in addition to graft transmission. In general, marafiviruses are not known to be seed transmitted (Martelli et al. 2002) but some species are insect vectored. MRFV, OBDV, Bermuda grass etched-line virus, and the putative marafivirus SwMV are vectored by leafhoppers (Agindotan et al. 2013; Banttari and Zeyen 1970; Gamez and Leon 1985; Lockhart et al. 1985), whereas CSDaV is potentially vectored by aphids (Maccheroni et al. 2005). Luteoviruses are also not known to be seed transmitted but are vectored by aphids (Gildow 1999). Of immediate importance to the fruit tree industry in the United States is the identification of vector species, economic impact of the viruses, and prevalence of these viruses in grower, nursery, and foundation orchards.

$\mathrm{NSPaV}$ was previously sequenced from composite samples of SF04522, SF05211, and SF06176 nectarine accessions (Bag et al. 2015), all of which are represented in this study. However, NeVM was not previously reported (Bag et. al. 2015). Although identical HTS platforms were used in both studies (HiSeq2000 Illumina 50-bp single-end read sequencing), the previous study used doublestranded (ds)RNA as templates for sequencing whereas total RNA was used in the present study. The failure of HTS to reveal NeVM from dsRNA preparation suggests a low abundance of NeVMspecific dsRNA in the pooled samples. Both marafiviruses and luteoviruses are known to occur at low titer in their hosts (Banttari and Zeyen 1969). Moreover, as demonstrated above, the time and type of tissue used for analysis was critical for detection by HTS. Notwithstanding the discovery of both NSPaV and NeVM using total RNA preparations, this study unmasks a limitation of HTS relating to certain low-titer viruses. This is illustrated by the discrepancies between the HTS (and RT-PCR) results for the original budwood of the three samples SF05211, SF06176, and SF07176 and subsequent RT-PCR testing of the reference trees of the respective samples. Because RT-PCR testing of the original budwood concurred with HTS results for these samples, this limitation would not have been circumvented by using any of the pathogen-testing protocols employed. The use of small RNA as nucleic acid templates for HTS might address this limitation but this method needs further evaluation for overall utility.

It is also important to reiterate that novel pathogens, as in the case of NSPaV and NeVM, could not have been detected by RTPCR without the availability of the genomic sequence information of these two viruses made possible by HTS. Overall, these results provide further support of the adoption of HTS as an integral component of pathogen-testing protocols at clean plant centers but its utility must be done with circumspection. Two HTS applications for each fruit tree accession would be a practical approach to incorporate this technology: one at the time of receipt of dormant budwood and another after reference trees are propagated and allowed to grow for 6 to 8 months to allow replication of low-tittered viruses and other pathogens to reach detectable levels.

The identification of novel viruses has a direct impact on fruit tree quarantine programs worldwide. Planting materials may need to be screened for $\mathrm{NSPaV}$ and $\mathrm{NeVM}$. Specific primers for these viruses based on available sequence data are described in this article. Although the current virus-testing procedures (biological, serological, and molecular assays) for fruit trees have dramatically improved the phytosanitary status of planting materials, their limitations have been exposed with the discovery of these novel viruses through HTS. The shortcoming of conventional testing protocols has been also revealed for grapevines (Al Rwahnih et al. 2015); it seems likely that HTS technology may become a viable option for perennial crop virus detection.

\section{ACKNOWLEDGMENTS}

This study was supported, in part, by the Department of Plant Pathology, College of Agricultural, Human, and Natural Resource Sciences Agricultural Research Center Washington State University, Pullman 99164-6240 and United States Department of Agriculture National Institute of Food and Agriculture project number WNP 00754. We thank the Washington Tree Fruit Research Commission; the Washington State Department of Agriculture Nursery License Fee Research Program; and the California Department of Food and Agriculture California Fruit Tree, Nut Tree, and Grapevine Improvement Advisory Board for funding.

\section{LITERATURE CITED}

Adams, I. P., Glover, R. H., Monger, W. A., Mumford, R., Jackeviciene, E., Navalinskiene, M., Samuitiene, M., and Boonham, N. 2009. Next-generation sequencing and metagenomic analysis: A universal diagnostic tool in plant virology. Mol. Plant Pathol. 10:537-545.

Agindotan, B. O., Gray, M. E., Hammond, R. W., and Bradley, C. A. 2012. Complete genome sequence of switchgrass mosaic virus, a member of a proposed new species in the genus Marafivirus. Arch. Virol. 157:18251830.

Agindotan, B. O., Prasifka, J. R., Gray, M. E., Dietrich, C. H., and Bradley, C. A. 2013. Transmission of Switchgrass mosaic virus by Graminella aureovittata. Can. J. Plant Pathol. 35:384-389. 
Al Rwahnih, M., Daubert, S., Golino, D., Islas, C., and Rowhani, A. 2015. Comparison of next-generation sequencing versus biological indexing for the optimal detection of viral pathogens in grapevine. Phytopathology 105: 758-763.

Al Rwahnih, M., Daubert, S., Golino, D., and Rowhani, A. 2009. Deep sequencing analysis of RNAs from a grapevine showing Syrah decline symptoms reveals a multiple virus infection that includes a novel virus. Virology 387:395-401.

Al Rwahnih, M., Daubert, S., Úrbez-Torres, J. R., Cordero, F., and Rowhani, A. 2011. Deep sequencing evidence from single grapevine plants reveals a virome dominated by mycoviruses. Arch. Virol. 156:397-403.

Al Rwahnih, M., Uyemoto, J. K., Falk, B. W., and Rowhani, A. 2007. Molecular characterization and detection of plum bark necrosis stem pittingassociated virus. Arch. Virol. 152:2197-2206.

Bag, S., Al Rwahnih, M., Li, A., Gonzalez, A., Rowhani, A., Uyemoto, J. K., and Sudarshana, M. R. 2015. Detection of a new luteovirus in imported nectarine trees: A case study to propose adoption of metagenomics in postentry quarantine. Phytopathology 105:840-846.

Bajet, N. B., Unruh, T. R., Druffel, K. L., and Eastwell, K. C. 2008. Occurrence of two little cherry viruses in sweet cherry in Washington State. Plant Dis. 92:234-238.

Banttari, E. E., and Zeyen, R. J. 1969. Chromatographic purification of the oat blue dwarf virus. Phytopathology 59:183-186.

Banttari, E. E., and Zeyen, R. J. 1970. Transmission of Oat blue dwarf virus by the aster leafhopper following natural acquisition or inoculation. Phytopathology 60:399-402.

Barba, M., Hadidi, A., Candresse, T., and Cambra, M. 2011. Plum pox virus. Pages 185-198 in: Virus and Virus-like Diseases of Pome and Stone Fruits. A. Hadidi, M. Barba, T. Candresse, and W. Jelkmann, eds. American Phytopathological Society, St. Paul, MN.

Brault, V., Van Den Heuvel, J. F., Verbeek, M., Ziegler-Graff, V., Reutenauer, A., Herrbach, E., Garaud, J. C., Guilley, H., Richards, K., and Jonard, G. 1995. Aphid transmission of beet western yellows luteovirus requires the minor capsid read-through protein P74. EMBO J. 14:650-659.

Chay, C. A., Gunasinge, U. B., Dinesh-Kumar, S. P., Miller, W. A., and Gray, S. M. 1996. Aphid transmission and systemic plant infection determinants of barley yellow dwarf luteovirus-PAV are contained in the coat protein readthrough domain and 17-kDa protein, respectively. Virology 219:57-65.

Coetzee, B., Freeborough, M. J., Maree, H. J., Celton, J.-M., Rees, D. J. G., and Burger, J. T. 2010. Deep sequencing analysis of viruses infecting grapevines: Virome of a vineyard. Virology 400:157-163.

Domier, L. L. 2012. Family Luteoviridae. Pages 1045-1053 in: Virus Taxonomy, 9th ed. M. Q. K. Andrew, L. Elliot, J. A. Michael, and E. B. Carstens, eds. Elsevier Academic Press, London, UK.

Domier, L. L., McCoppin, N. K., Larsen, R. C., and D’Arcy, C. J. 2002. Nucleotide sequence shows that Bean leafroll virus has a luteo-like genome organization. J. Gen. Virol. 83:1791-1798.

Donaire, L., Wang, Y., Gonzalez-Ibeas, D., Mayer, K. F., Aranda, M. A., and Llave, C. 2009. Deep sequencing of plant viral small RNAs reveals effective and widespread targeting of viral genomes. Virology 392:203-214.

Dreher, T. W., Edwards, M. C., Gibbs, A. J., Haenni, A. L., Hammond, R. W., Jupin, I., Koenig, R., Sabanadzovic, S., Ahou Ghanem-Sabanadzovic, N., and Martelli, G. P. 2005. Family Tymoviridae. Pages 1067-1076 in: Virus Taxonomy: Eighth Report of the International Committee on Taxonomy of Viruses. C. M. Fauquet, M. A. Mayo, J. Maniloff, U. Desselberger, and L. A. Ball, eds. Elsevier Academic Press, London, UK.

Eastwell, K. C., and Bernardy, M. G. 2001. Partial characterization of a closterovirus associated with mealybug-transmitted little cherry disease in North America. Phytopathology 91:268-273.

Eastwell, K. C., Dutoit, L. J., and Druffel, K. L. 2009. Helleborus net necrosis virus: A new Carlavirus associated with 'black death' of Helleborus spp. Plant Dis. 93:332-338.

Edgar, R. C. 2004. MUSCLE: Multiple sequence alignment with high accuracy and high throughput. Nucleic Acids Res. 32:1792-1797.

Edwards, M. C., Zhang, Z., and Weiland, J. J. 1997. Oat blue dwarf marafivirus resembles the tymoviruses in sequence, genome organization, and expression strategy. Virology 232:217-229.

Elbeaino, T., Giampetruzzi, A., De Stradis, A., and Digiaro, M. 2014. Deepsequencing analysis of an apricot tree with vein clearing symptoms reveals the presence of a novel betaflexivirus. Virus Res. 181:1-5.

Foissac, X., Svanella-Dumas, L., Gentit, P., Dulucq, M. J., Marais, A., and Candresse, T. 2005. Polyvalent degenerate oligonucleotides reverse transcription-polymerase chain reaction: A polyvalent detection and characterization tool for trichoviruses, capilloviruses, and foveaviruses. Phytopathology 95:617-625.

Gamez, R., and Leon, P. 1985. Ecology and evolution of a neotropical leafhopper-virus-maize association. Pages 331-349 in: The Leafhoppers and Planthoppers. L. R. Nault and J. G. Rodriguez, eds. John Wiley \& Sons Inc., New York.
Giampetruzzi, A., Roumi, V., Roberto, R., Malossini, U., Yoshikawa, N., La Notte, P., Terlizzi, F., Credi, R., and Saldarelli, P. 2012. A new grapevine virus discovered by deep sequencing of virus- and viroid-derived small RNAs in cv. Pinot gris. Virus Res. 163:262-268.

Gildow, F. E. 1999. Luteovirus transmission and mechanisms regulating vector specificity. Pages 88-113 in: The Luteoviridae. H. G. Smith and H. Barker, eds. CAB International, Oxon, UK.

Hadidi, A. and Barba, M. 2011. Economic impact of pome and stone fruit viruses and viroids. Pages 9-12 in: Virus and Virus-like Diseases of Pome and Stonefruits. A. Hadidi, M. Barba, T. Candresse, and W. Jelkmann, eds. American Phytopathological Society, St. Paul, MN.

Hall, T. A. 1999. BioEdit: A user-friendly biological sequence alignment editor and analysis program for Windows 95/98/NT. Nucleic Acids Symp. Ser. 41:95-98.

Hammond, R. W., and Ramirez, P. 2001. Molecular characterization of the genome of Maize rayado fino virus, the type member of the genus Marafivirus. Virology 282:338-347.

He, Y., Yang, Z., Hong, N., Wang, G., Ning, G., and Xu, W. 2015. Deep sequencing reveals a novel closterovirus associated with wild rose leaf rosette disease. Mol. Plant Pathol. 16:449-458.

Jelkmann, W. 1995. Cherry virus A: cDNA cloning of dsRNA, nucleotide sequence analysis and serology reveal a new plant capillovirus in sweet cherry. J. Gen. Virol. 76:2015-2024.

Jelkmann, W. 2004. Detection of virus and virus-like diseases of fruit trees laboratory assays, bioassays and indicators. Pages 575-596. Proc. 19th Int. Symp. Virus Virus-like Dis. Temperate Fruit Crops: Fruit Tree Dis. G. Llacer ed. International Society for Horticultural Science, Leuven, Belgium.

King, A. M. Q., Adams, M. J., Carstens, E. B., and Lefkowitz, E. J., eds. 2012. Virus Taxonomy: Ninth Report of the International Committee on Taxonomy of Viruses. Elsevier Academic Press, London, UK.

Kreuze, J. F., Perez, A., Untiveros, M., Quispe, D., Fuentes, S., Barker, I., and Simon, R. 2009. Complete viral genome sequence and discovery of novel viruses by deep sequencing of small RNAs: A generic method for diagnosis, discovery and sequencing of viruses. Virology 388:1-7.

Kusano, N., and Shimomura, K. 1997. Selection of PCR primers and a simple extraction method for detection of hop stunt viroid-plum in plum by reverse transcription-polymerase chain reaction. Ann. Phytopathol. Soc. Jpn. 63: 119-123.

Laimer, M., and Barba, M. 2011. Elimination of systemic pathogens by thermotherapy, tissue culture, or in vitro micrografting. Pages 391-396 in: Virus and Virus-like Diseases of Pome and Stonefruits. A. Hadidi, M. Barba, T. Candresse, and W. Jelkmann, eds. American Phytopathological Society, St. Paul, MN.

Larsen, H. J., Yu, K. S., and Hatch, A. H. 1998. Expression of peach mosaic symptoms in nectarine and peach cultivars. Acta Hortic. 472:281-284.

Lockhart, B. E. L., Khaless, N., Lennon, A. M., and El Maataoui, M. 1985. Properties of Bermuda grass etched-line virus, a new leafhopper-transmitted virus related to maize rayado fino and oat blue dwarf viruses. Phytopathology 75:1258-1262.

Maccheroni, W., Alegria, M. C., Greggio, C. C., Piazza, J. P., Kamla, R. F., Zacharias, P. R., Bar-Joseph, M., Kitajima, E. W., Assumpcao, L. C., Camarotte, G., Cardozo, J., Casagrande, E. C., Ferrari, F., Franco, S. F., Giachetto, P. F., Girasol, A., Jordao, H., Jr., Silva, V. H., Souza, L. C., Aguilar-Vildoso, C. I., Zanca, A. S., Arruda, P., Kitajima, J. P., Reinach, F. C., Ferro, J. A., and da Silva, A. C. 2005. Identification and genomic characterization of a new virus (Tymoviridae family) associated with citrus sudden death disease. J. Virol. 79:3028-3037.

Marais, A., Faure, C., Mustafayev, E., Barone, M., Alioto, D., and Candresse, T. 2015. Characterization by deep sequencing of Prunus virus T, a novel tepovirus infecting Prunus species. Phytopathology 105:135-140.

Martelli, G. P., Flores, R., and Schneider, B. 2011. Classification of pome and stone fruit viruses, viroids and phytoplasma. Pages 13-16 in: Virus and Virus-like Diseases of Pome and Stonefruits. A. Hadidi, M. Barba, T. Candresse, and W. Jelkmann, eds. American Phytopathological Society, St. Paul, MN

Martelli, G. P., Sabanadzovic, S., Abou Ghanem-Sabanadzovic, N., Edwards, M. C., and Dreher, T. 2002. Virology division news: The family Tymoviridae. Arch. Virol. 147:1838-1846.

Menzel, W., Jelkmann, W., and Maiss, E. 2002. Detection of four apple viruses by multiplex RT-PCR assays with coamplification of plant mRNA as internal control. J. Virol. Methods 99:81-92.

Miller, W. A., Dinesh-Kumar, S. P., and Paul, C. P. 1995. Luteovirus gene expression. Curr. Rev. Plant Sci. 14:179-211.

Minsavage, G. V., Thompson, C. M., Hopkins, D. L., Leite, R. M. V. B. C., and Stall, R. E. 1994. Development of a polymerase chain reaction protocol for detection of Xylella fastidiosa in plant tissue. Phytopathology 84:456-461.

Poojari, S., Alabi, O. J., Fofanov, V. Y., and Naidu, R. N. 2013. A leafhoppertransmissible DNA virus with a novel evolutionary lineage in the family 
Geminiviridae implicated in grapevine redleaf disease by next-generation sequencing. PLoS One 8:e64194.

Powell, C. A., Hadidi, A., and Halbrendt, J. M. 1991. Detection of Tomato ringspot virus in nectarine trees using ELISA and transcribed RNA probes. HortScience 26:1290-1292.

Radford, A. D., Chapman, D., Dixon, L., Chantrey, J., Darby, A. C., and Hall, N. 2012. Application of next-generation sequencing technologies in virology. J. Gen. Virol. 93:1853-1868.

Skrzeczkowski, L. J., Howell, W. E., Eastwell, K. C., and Cavileer, T. D. 2001. Bacterial sequences interfering in detection of phytoplasma by PCR using primers derived from the ribosomal RNA operon. Acta Hortic. 550:417-424.

Tamura, K., Stecher, G., Peterson, D., Filipski, A., and Kumar, S. 2013. MEGA6: Molecular Evolutionary Genetics Analysis, Version 6.0. Mol. Biol. Evol. 30: 2725-2729.
USDA-NASS. 2014. Non-citrus fruits and nuts: 2013 summary. Online publication. United States Department of Agriculture-National Agricultural Statistics Service. http://www.agcensus.usda.gov/Publications/2012/Full_Report/ Volume_1,_Chapter_2_US_State_Level/st99_2_031_031.pdf

Villamor, D. E. V., and Eastwell, K. C. 2013. Viruses associated with rusty mottle and twisted leaf diseases of sweet cherry are distinct species. Phytopathology 103:1287-1295.

Villamor, D. E. V., Susaimuthu, J., and Eastwell, K. C. 2015. Genomic analyses of cherry rusty mottle group and cherry twisted leaf-associated viruses reveal a possible new genus within the family Betaflexiviridae. Phytopathology 105:399-408.

Vives, M. C., Velazquez, K., Pina, J. A., Moreno, P., Guerri, J., and Navarro, L. 2013. Identification of a new enamovirus associated with citrus vein enation disease by deep sequencing of small RNAs. Phytopathology 103:1077-1086. 